\title{
THE ANALYSIS OF THE DIGITAL AC MOTOR SPEED CONTROL SYSTEM OPERATION
}

\section{Joanna Sznajder}

Polish Naval Academy, Faculty of Mechanical and Electrical Engineering, Śmidowicza 69 Str., 81-127 Gdynia, Poland; e-mail: j.sznajder@amw.gdynia.pl

\begin{abstract}
The article presents the analysis of the automatic alternate current motor control system, carried out by the author. The automatic control system has been implemented on the existing laboratory stand, containing: the squirrel-cage asynchronous motor and the frequency inverter. The existing stand imposed one of the available speed control methods for the motor and the necessity of the appropriate elements selection for the automatic control system [1]. The automatic control system has been designed and created as the constant value follow-up digital controller. To designate the parameters of the control object the unit step method of was used. After registering the output changes caused by the unit step, the characteristic curve was received that allowed to determine the alternative transmittance of the control object which, in turn, has made possible to find the appropriate controller settings.
\end{abstract}

Key words:

PID controller, Arduino, automatic control system.

Research Article

(C) 2018 Joanna Sznajder This is an open access article licensed under the Creative Commons Attribution-NonCommercial-NoDerivatives 4.0 license (http://creativecommons.org/licenses/by-nc-nd/4.0/) 


\section{INTRODUCTION}

In the past century the manual control was quite popular, which was to enter the set value by the operator. That kind of system belongs to open-loop type, which means, that it did not need to compare the value obtained at the output with the set value. The system under the manual control depends on its operator's skill. Additionally, there are always interferences in the system environment, which cannot be eliminated, because of their stochastic nature. The automatic control in a closed-loop system allows controlling the state of the object, by measuring, and then comparing the output signal value with the set value. The measurement allows incorporating the impact of the occurring distortions. By comparing the set value with the value of the output signal, the so-called error term is obtained. Based on the measured parameters, the system works out the decision, so as to minimise the difference between compared values. Like that designed system allows improving the safety, quality and reliability of the process that is being controlled.

A closed-loop control system consists of the main path and feedback path. In order to achieve an automatic control system the three components are required: the sensor allowing to determine the state of the system, actuators responsible for working out the input signal, and the controller responsible for the execution of the master program that resides in its memory and for working out the decision based on the data collected from the system [2].

The chosen controller is a digital, tracking, and constant-value one. Digital controller means that the measurement performed by the sensors and the input set value are converted to the digital signal, and hence are expressed in a numerical form. The calculation of displacement - the control deviation and the adjusting signal is performed via digital operations. The conversion to the analogue signal is subjected the adjusting signal, which is the output signal from the controller [4]. In the steady state, it is important for controller to maintain the constant value of the specified signal regardless of the interferences occurring in the object environment. Such system is called the constant value system [4].

The user can arbitrary change the AC motor speed from zero to its nominal speed. After examining the principles of system operation, prior to modernization, it was concluded that the adjustment system should observe the changes of the set value in order to match the value of the controlled signal, so that they correspond to the required signal. This type of control is the tracking system. In the system of the required value is not specified as the function of time. The main disruption for the object is to change of the required value. The task of the tracking system is to 
compare the value of the output signal with the object's output signal and setting of the control signal to compensate for a possible difference between the compared signals [4].

In the literature, one may encounter the classification of objects under the characteristic, which relays on achieving a sustainable balance upon discontinuation of the unit step excitation. Such objects are divided into static objects (without integration) and non static objects (with integration). The main feature of static objects is the fact that after a sufficient long time they reach new steady states. The unit step characteristics of non static objects do not reach steady states and are characterized by growth courses. The alternative transmittance of a static object is characterized by the presence of an inert element and possibly a delaying element. The alternative transmittance of a non static object also contains an integrating element.

The real operator transmittances can be difficult to determine analytically, in addition, if the properties of the object are not sufficiently known, or in general are not known at all, then the determination of the alternative operator transmittance based on the unit step characteristics is used. The alternative operator transmittance allows to know approximately the actual properties of the object.

The figure 1 shows an example response to unit step of a static object with a delay.
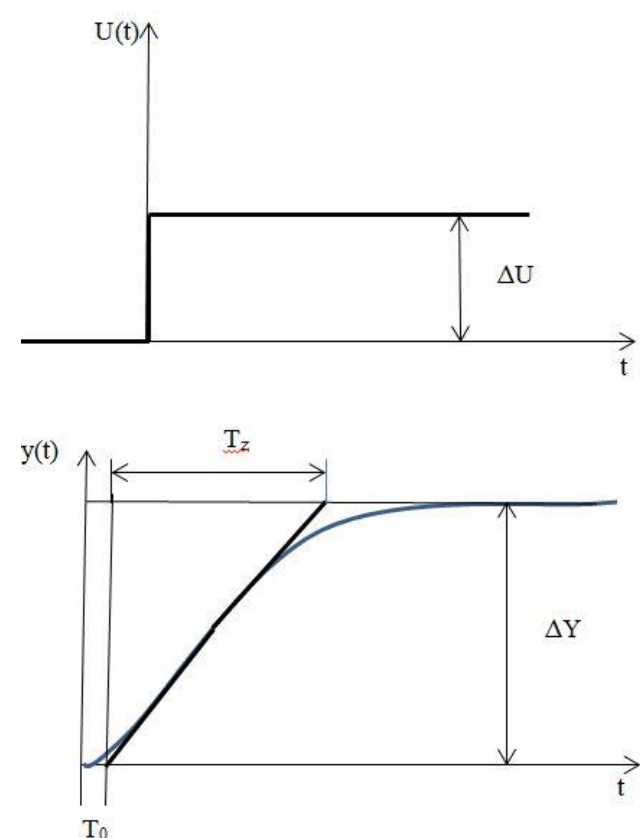

Fig. 1. The unit step characteristic of the static object with the marked time constants [own study]

1 (212) 2018 
There have been marked the time constants, i.e. $T_{0}$ - the object's alternative delay, $T_{z}-$ the object's alternative time constant. The object's gain factor is expressed by the formula [6]:

$$
k_{0}=\frac{\Delta y}{\Delta u} .
$$

Based on the above characteristic, the alternative object model along with the alternative operator transmittance can be determined [6]:

$$
G(s)=\frac{k_{0}}{T_{z} s+1} \cdot e^{-T_{0} s}=G_{1} s \cdot G_{2} s .
$$

Where the transmittance of the inert element is expressed by the formula [6]:

$$
G_{1}(s)=\frac{k_{0}}{T_{z} s+1} .
$$

While, the transmittance of the delay element is represented by [6]:

$$
G_{2}(s)=e^{-T_{o} s} .
$$

An important factor is the gain factor of the object. The higher the value, the worse regulatory properties the object offers.

The implemented automatic controller system is a centralized system that has been designed and made using the Arduino UNO microcontroller. The microcontroller based, on the implemented program controls the speed in such a way, that the actual speed should achieve the set speed [3].

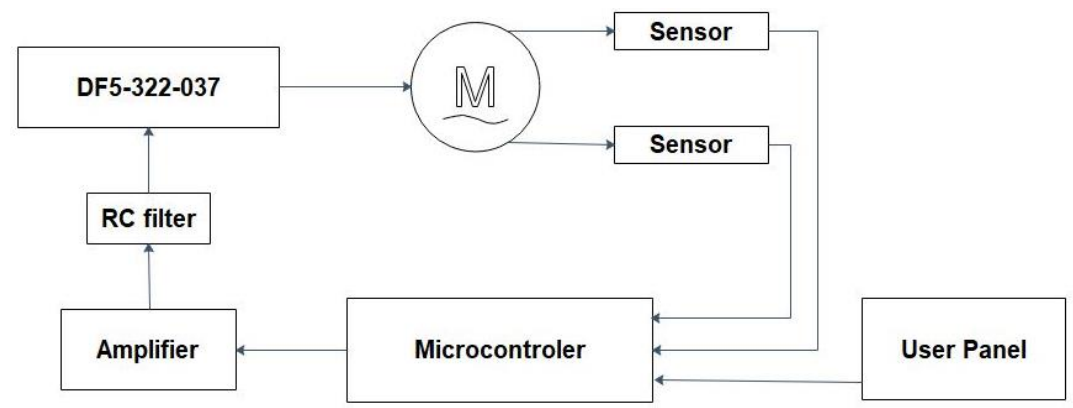

Fig. 2. The scheme of the automatic control system [3]

\section{RESEARCH METHODOLOGY AND THE TEST RESULTS}

To elaborate the data obtained from the microprocessor laboratory stand (fig. 2) the environment of MATLAB/Simulink was used. For the control object's 
transmittance was not known, hence the method of the response to the unit step for of determining the alternative transmittance was used. As the unit step the speed equal to $292 \mathrm{rev} / \mathrm{min}$, what corresponds to $10.6 \mathrm{~Hz}$ for the frequency inverter, and requires to set the voltage from the control system to $2.12 \mathrm{~V}$. The results of the measurements are presented in table 1.

Tab. 1. The response object to the stroke unit [own study]

\begin{tabular}{|c|c|c|}
\hline No. & Time & Speed \\
\hline 0 & 0 & 0 \\
\hline 1 & 0.5 & 150 \\
\hline 2 & 1 & 200 \\
\hline 3 & 1.5 & 250 \\
\hline 4 & 2 & 280 \\
\hline 5 & 2.5 & 283 \\
\hline 6 & 3 & 285 \\
\hline 7 & 3.5 & 284 \\
\hline 8 & 4 & 285 \\
\hline 9 & 4.5 & 285 \\
\hline 10 & 5 & 284 \\
\hline 11 & 5.5 & 285 \\
\hline 12 & 6 & 285 \\
\hline
\end{tabular}

On the basis of the above measurements the characteristic curve, showing the dependence of the AC motor speed without regulation was established.

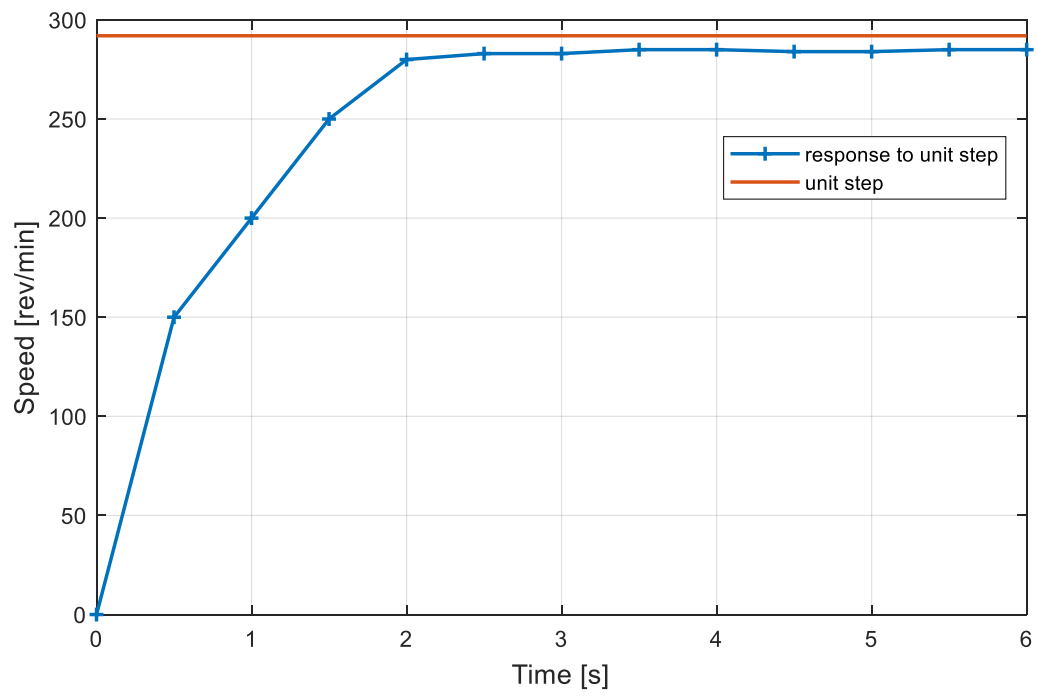

Fig. 3. The response of the object to the unite step [own study]

1 (212) 2018 
It can be concluded from the course of characteristic curve that the object under regulation is of the inert type.

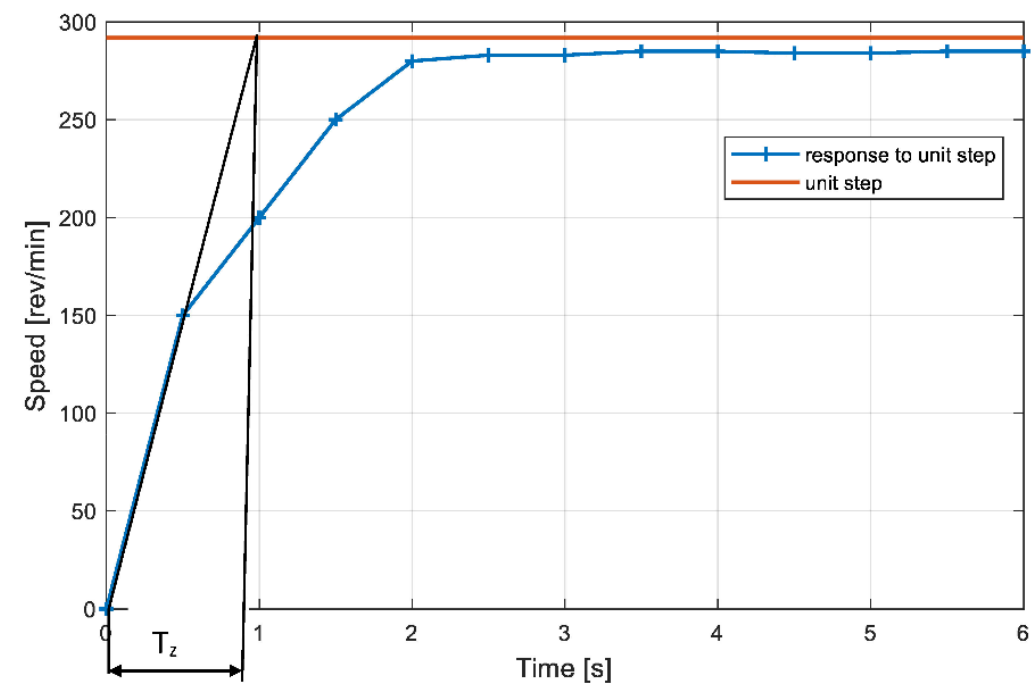

Fig. 4. The object's response to the unite step - the determination of parameters for the alternative transmittance [own study]

From the characteristic curve the following parameters were read off: the alternative time constant $\mathrm{T}_{\mathrm{z}}$, the object gain coefficient:

$$
\begin{gathered}
T_{z}=0.8 ; \\
k_{0}=\frac{\Delta y}{\Delta u}=\frac{280}{292}=0.96 .
\end{gathered}
$$

With a view to earlier determined parameters, the object's alternative transmittance was determined:

$$
G_{0}=\frac{0.96}{0.8 s+1}
$$

Based on the determined model's the alternative transmittance, in Matlab/ Simulink program, the characteristic curve showing the system response to the unit step excitation was created:

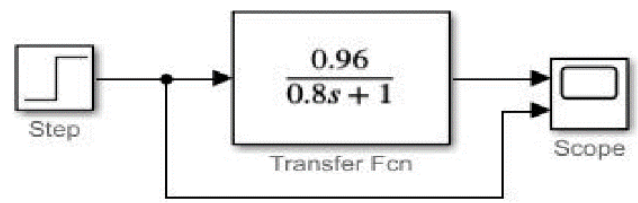

Fig. 5. Model used to simulate the response to the unit step [own study] 
The comparison of the responses to the unit step of the model and the object was shown on the figure 6.

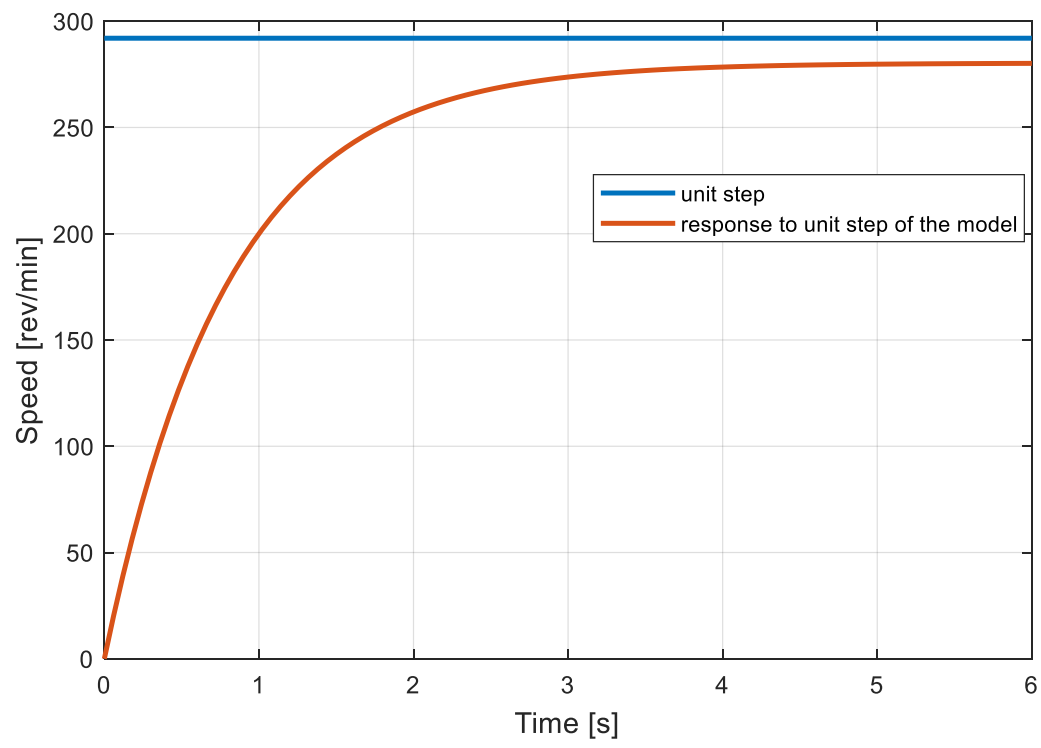

Fig. 6. The simulation of the object's response to the unit step [own study]

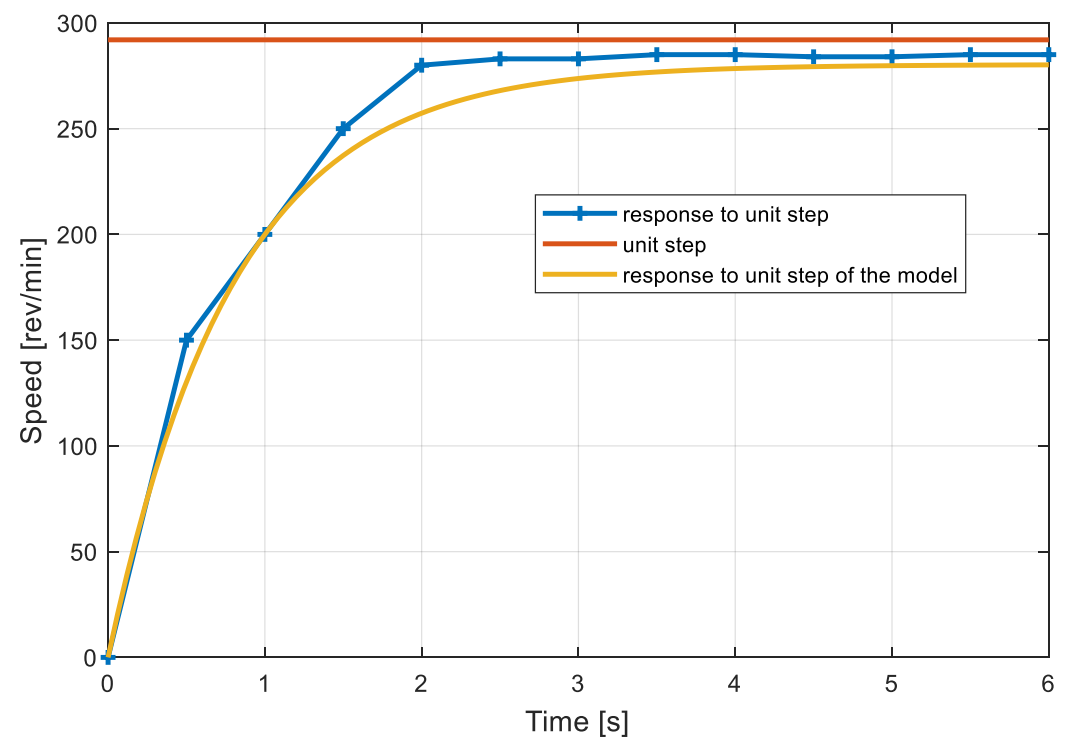

Fig. 7. The comparison of the responses to the unit step of the model and the object [own study] 
The responses to the step unit, both of the object and the model revealed that the output signal does not reach the value specified, and hence a deviation occurs in the steady state. This was the premise to realize the PID controller, which would improve the object speed control.

As the most important regulating factor, the principle that the output signal should reach the required value in the shortest possible time was adopted. The PID control settings were selected using Ziegler-Nichols method. This method comprises three indicators. The first indicator: the non periodic response $(\kappa=0 \%)$ with the minimum setting time $\left(t_{r} \rightarrow \min \right)$. The second indicator: the requirement for the minimum settling time $\left(t_{r} \rightarrow \min \right)$, however, the oscillations are permissible $(\kappa=20 \%)$. In the third indicator, the idea to minimize the integral square error, ISE [5]. The best results were obtained by applying the second indicator, which is the minimum time setting and oscillation allowing. The calculated parameters formed the basis of the PID control tuning. It turned out that by reducing the proportional element the characteristic curve that more closely corresponded to the established requirements was received. The following settings of controller were acknowledged: proportional element: 0.9, the derivative element: 0.25 , integrating element: 1.2 .

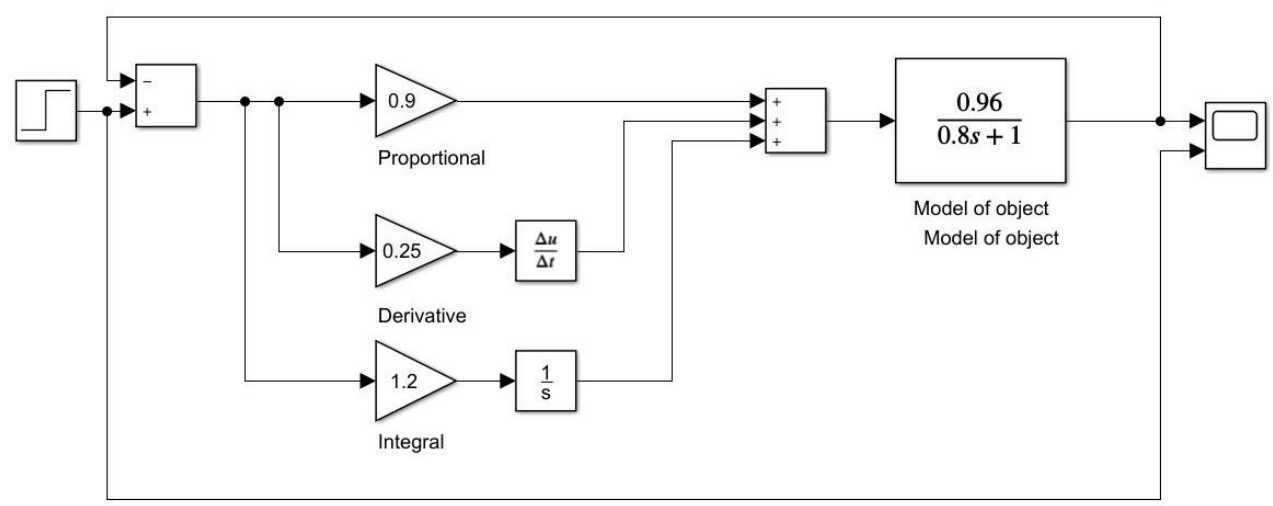

Fig. 8. The PID controller model implemented in MATLAB/Simulink environment [own study]

The simulation the object model response with the PID controller revealed a possible realignment, however, its value is not significant, and as it is around 1\%. After the evaluation of regulator parameters and performing the simulation, examinations were conducted that validated the selected parameters. The results of the measurements are presented in table 2 . 


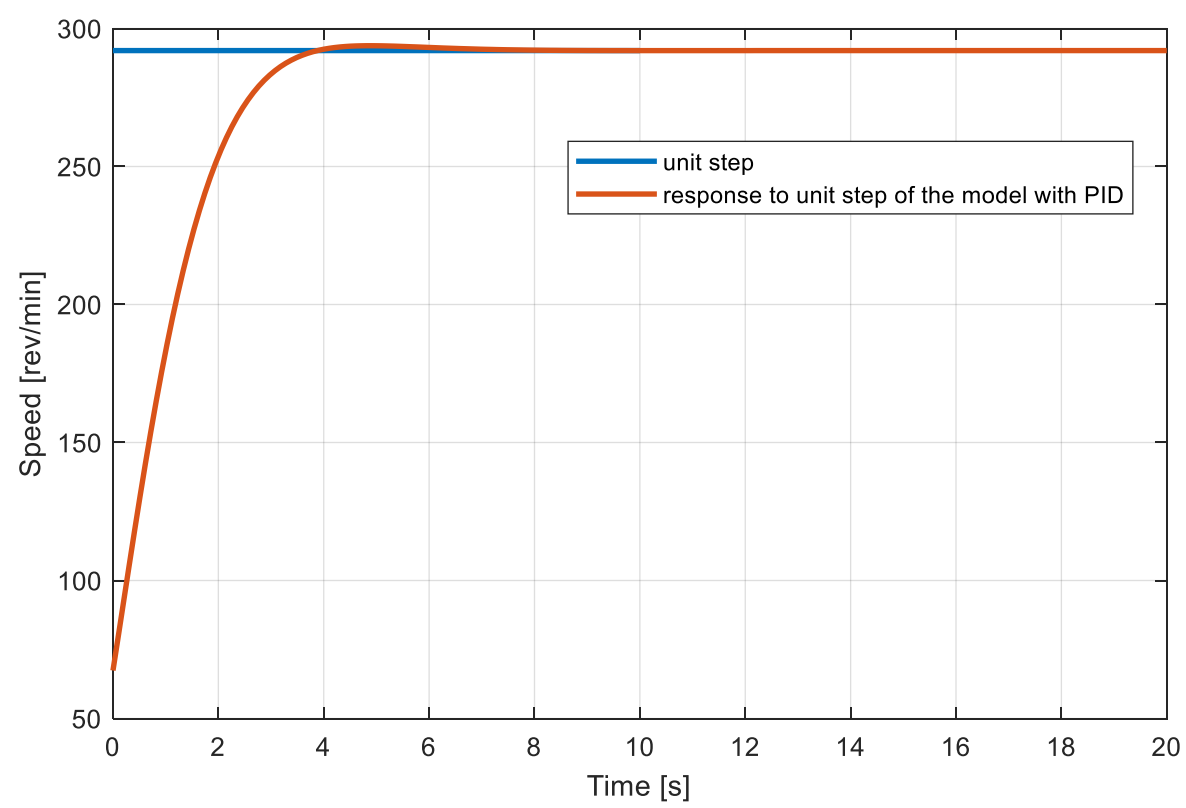

Fig. 9. The simulation of the PID controller response [own study]

Tab. 2. The response of the object with the controller on the unit step [own study]

\begin{tabular}{|c|c|c|}
\hline No. & Time $[\mathbf{s}]$ & Speed $[\mathbf{r e v} / \mathbf{m i n}]$ \\
\hline 0 & 0 & 0 \\
\hline 1 & 0.5 & 100 \\
\hline 2 & 1 & 160 \\
\hline 3 & 1.5 & 240 \\
\hline 4 & 2 & 270 \\
\hline 5 & 2.5 & 280 \\
\hline 6 & 3 & 285 \\
\hline 7 & 3.5 & 292 \\
\hline 8 & 4 & 292 \\
\hline 9 & 4.5 & 292 \\
\hline 10 & 5 & 291 \\
\hline 11 & 5.5 & 292 \\
\hline
\end{tabular}




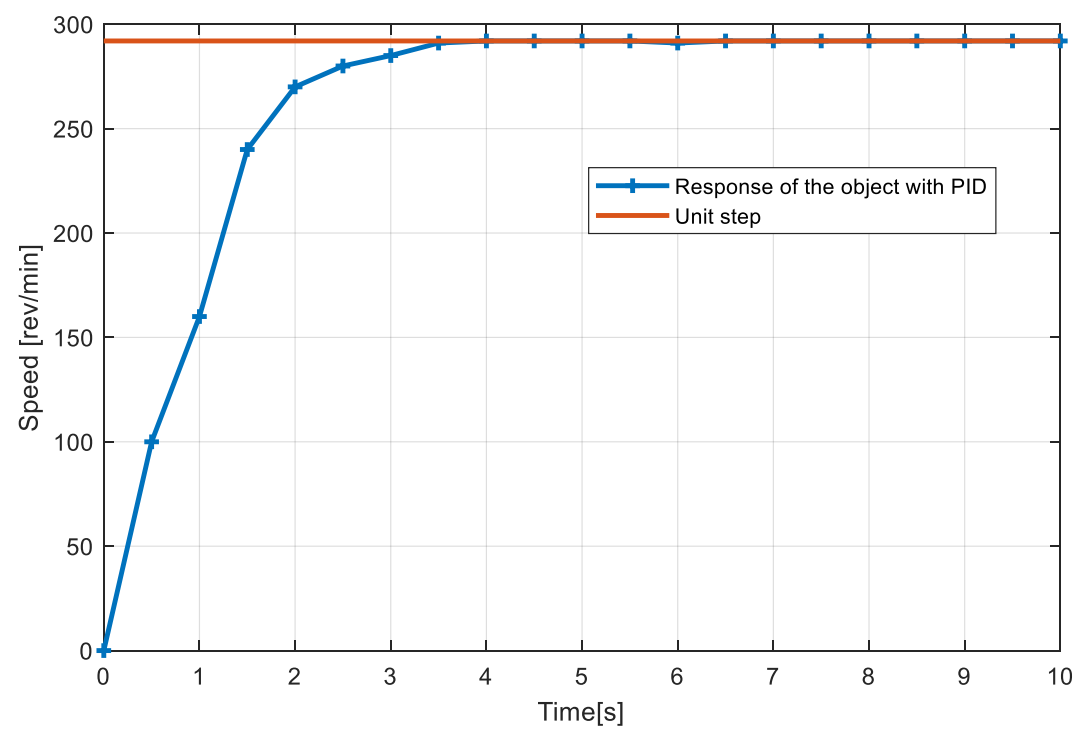

Fig. 10. The response of the object with the controller on the unit step [own study]

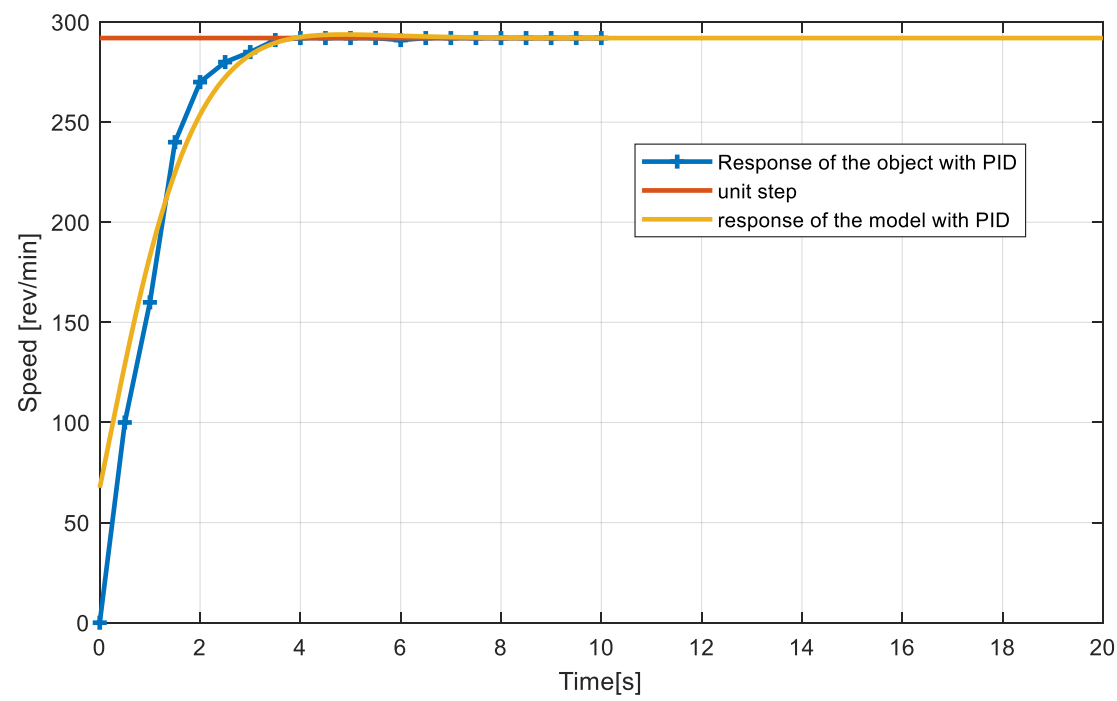

Fig. 11. The comparison of responses to the unit step of the object and the model with the PID controller [own study]

The object's alternative transmittance was chosen with the accuracy of about $1 \%$. This is confirmed by the calculations presented in table 3 . The table presents the averaged data both from the measurements and from the characteristic curves that show the response of the model to the unit step. 
Tab. 3. The results of the accuracy analysis of the object's alternative transmittance evaluation [own study]

\begin{tabular}{|c|c|c|c|}
\hline 1 & \multicolumn{3}{|c|}{ The accuracy of the model without the controller } \\
\hline 2 & The unit step & 292 & $\mathrm{rev} / \mathrm{min}$ \\
\hline 3 & Actual speed & 285 & $\mathrm{rev} / \mathrm{min}$ \\
\hline 4 & The speed of the model & 280.1 & $\mathrm{rev} / \mathrm{min}$ \\
\hline 5 & Steady-state deviation & 7 & $\mathrm{rev} / \mathrm{min}$ \\
\hline \multirow[t]{3}{*}{6} & Absolute error & 4,9 & $\mathrm{rev} / \mathrm{min}$ \\
\hline & The relative standard error & 1.72 & $\%$ \\
\hline & \multicolumn{3}{|c|}{ The accuracy of the model with the controller } \\
\hline 1 & The unit step & 292 & $\mathrm{rev} / \mathrm{min}$ \\
\hline 2 & Actual speed & 291.77 & $\mathrm{rev} / \mathrm{min}$ \\
\hline 3 & The speed of the model & 293.65 & $\mathrm{rev} / \mathrm{min}$ \\
\hline 4 & Steady-state deviation & 0.23 & $\mathrm{rev} / \mathrm{min}$ \\
\hline 5 & Absolute error & 1.88 & $\mathrm{rev} / \mathrm{min}$ \\
\hline 6 & The relative standard error & 0.64 & $\%$ \\
\hline
\end{tabular}

\section{CONCLUSIONS}

The use of the step unit method allowed to evaluate the alternative transmittance of the tested object with the good accuracy. It was testified by the carried out simulation of the object model response to the unit step in MATLAB/Simulink program. The tuning of the controller was carried out with the use of the Ziegler-Nichols method, which assumes the minimum time adjustments and accepts oscillations. The time adjustment equal to 3.5 seconds for the real object, the engine, is sufficiently good. The actual response of the adjusted object did not have the overshoot in its characteristics curve. The overshoots were in the simulation of response of the object with the controller, however, their values were insignificant. The direction of further research for the described laboratory stand will be fuzzy controllers.

\section{REFERENCES}

[1] Frequency Inverter DF5. Hardware and Engineering, safety instructions, Moeller GMbH, Bonn 2007, [online], ftp://ftp.moeller.net/DOCUMENTATION/AWB_MANUALS/h1541g.pdf [access 08.09.2017]. 
[2] Fundamentals of automation technology, technical book, Festo Didactic GmbH \& Co. KG, Denkendorf 2008, [online], https://lehrerfortbildung-bw.de/u_matnatech/nwt/gym/weiteres/ $\mathrm{fb} 1 /$ atechnik/grundlagen/en/kapitel/563060_Fundamentals_of_automation_technology.pdf [access 08.09.2017].

[3] Karwowska J., Analiza pracy układu sterowania prędkościq̨ obrotową silnika prądu przemiennego, master's dissertation, Gdynia 2016 [The analysis of AC motor speed control system operation - available in Polish].

[4] Lisowski J., Podstawy automatyki, Publ. Akademia Morska, Gdynia 2015 [Basics of automation — available in Polish].

[5] http://automatykab2b.pl/technika/9605-strojenie-pid---metody-doboru-nastaw-czesc-1\#. WdylzGh-pPZ [access 08.09.2017].

[6] http://iautomatyka.pl/laboratorium_automatyki/rozdz-34-wplyw-nieliniowosci-na-regulacje/ [access 10.09.2017].

\title{
ANALIZA PRACY UKLADU STEROWANIA PRĘDKOŚCIĄ OBROTOWĄ SILNIKA PRĄDU PRZEMIENNEGO
}

\author{
STRESZCZENIE
}

Artykuł zawiera analizę pracy układu sterowania prędkością obrotową silnika prądu przemiennego. Pomiary prędkości obrotowej silnika wykonane przed modernizacją ujawniły różnicę między prędkością zadaną a prędkością rzeczywistą wału silnika. Z tego powodu zdecydowano się zaimplementować na stanowisku regulator, który umożliwił minimalizację uchybu regulacji. Na podstawie otrzymanych pomiarów wyznaczono transmitancję zastępczą, która umożliwiła wykonanie modelu w programie MATLAB/Simulink. W artykule wykorzystano metodę strojenia regulatora - metodę Zieglera-Nicholsa, która opierała się na następujących założeniach: minimalnym czasie ustalania i dopuszczeniu oscylacji, które mogły wynosić do $20 \%$. Przeprowadzona symulacja wykazała, iż powyższa metoda przynosi korzystane rezultaty, które zostały potwierdzone w rzeczywistych pomiarach.

Słowa kluczowe:

regulator PID, Arduino, system sterowania automatycznego.

Article history

Received: 28.12.2017

Reviewed: 20.01.2018

Revised: $\quad 07.02 .2018$

Accepted: 08.02.2018 